http://ejournal.upi.edu/index.php/jaz - e-mail: jurnal.zonasi@gmail.com dan jurnal_zonasi@upi.edu doi.org/10.17509/jaz.v3i1.18621

\title{
PENGARUH BUKAAN TERHADAP PENCAHAYAAN ALAMI DAN PENGHAWAAN ALAMI PADA MASJID AL AHDHAR BEKASI
}

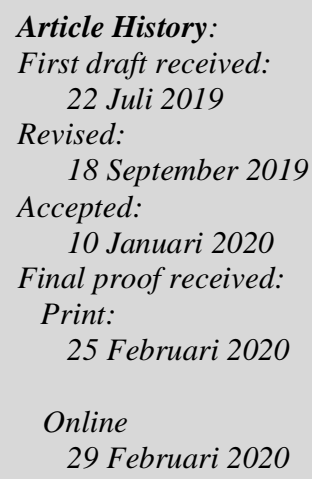

\author{
Christy Vidiyanti $^{1}$; Rodi Siswanto ${ }^{2}$; Febriansyah Ramadhan $^{3}$ \\ 1,2,3 Program Studi Arsitektur, Universitas Mercu Buana, Jakarta, Indonesia \\ Jl Meruya Selatan No.1, Kembangan, Jakarta Barat \\ Email: ${ }^{1}$ christy.vidiyanti@mercubuana.ac.id \\ 2rodisiswanto15@gmail.com \\ 3febrians94@gmail.com
}

\begin{abstract}
The building should be able to provide a comfortable space for users to avoid outside unfavorable climate, so that the activities in it can run optimally. The comfort aspect is one of the important factors in special worship in it. Al-Ahdhar Mosque is a mosque designed by architect Nataneka. This mosque has large openings so that natural lighting and natural ventilation can enter the building. However, it needs to be investigated whether this large opening is enough to influence the lighting conditions and conditions of the Al-Ahdhar mosque. This research was also conducted to find out the relationship between natural lighting and natural ventilation produced and to find out the opinions of respondents to the thermal comfort of the Al-Ahdhar mosque. The method used in this study is field measurements and observations which are then processed quantitatively. The results showed that natural lighting at Al-Ahdhar mosque was 180 lux on the 1st and 128th floors of lux on the 2nd floor, which meant that natural lighting in this mosque still did not meet the standards of 200 lux. Thermal conditions at Al-Ahdhar mosque, the lowest temperature of $240 C$ is found in areas that have openings of $34 \%$. While $80 \%$ openings produce temperatures that tend to be higher at 29.20C to 29.60C. Larger openings do not necessarily produce good natural lighting and air conditioning conditions. But keep in mind the location of openings, orientation of openings, and types of openings. The bigger the openings will also include large solar radiation as well.
\end{abstract}

Keywords: natural lighting; natural ventilation; thermal conditions; mosque

Abstrak: Bangunan sebaiknya dapat memberi ruang beraktivitas yang nyaman kepada pengguna agar terhindar dari iklim luar yang tidak menguntungkan, sehingga aktivitas di dalamnya dapat berjalan dengan optimal. Aspek kenyamanan merupakan salah satu faktor penting dalam kekhusukan beribadah di dalamnya. Masjid Al-Ahdhar merupakan masjid yang didesain oleh arsitek Nataneka. Masjid ini memiliki bukaan yang cukup besar sehingga pencahayaan alami dan penghawaan alami dapat masuk ke dalam bangunan. Namun, perlu diteliti apakah bukaan yang besar ini cukup berpengaruh terhadap kondisi pencahayaan dan kondisi penghawaan pada masjid Al-Ahdhar. Penelitian ini juga dilakukan untuk mengetahui hubungan antara pencahayaan alami dan penghawaan alami yang dihasilkan serta mengetahui pendapat responden terhadap kenyamanan termal masjid Al-Ahdhar. Metode yang dilakukan dalam penelitian ini adalah pengukuran lapangan dan observasi yang kemudian diolah secara kuantitatif. Hasil penelitian menunjukkan bahwa pencahayaan alami pada masjid Al-Ahdhar adalah sebesar 180 lux pada lantai 1 dan 128 lux pada lantai 2 yang berarti pencahayaan alami pada masjid ini masih belum memenuhi standar yaitu sebesar 200 lux. Kondisi thermal pada masjid Al-Ahdhar, suhu terendah yaitu sebesar 240C didapatkan pada area yang memiliki bukaan 34\%. Sedangkan bukaan $80 \%$ menghasilkan suhu udara yang cenderung lebih tinggi yaitu sebesar 29,20C sampai 29,60C. Bukaan yang semakin besar belum tentu menghasilkan kondisi pencahayaan alami dan penghawaan alami yang baik. Namun perlu diperhatikan letak bukaan, orientasi bukaan, dan jenis bukaan. Semakin besar bukaan juga akan memasukkan radiasi matahari yang besar pula.

Kata Kunci: pencahayaan alami; penghawaan alami; kondisi termal; masjid 


\section{Pendahuluan}

Pencahayaan dan penghawaan sebuah bangunan menjadi salah satu yang melatarbelakangi boros atau tidaknya penggunaan energi listrik. Desain bangunan yang tidak memperhatikan lingkungan sekitar menjadi penyebab borosnya penggunaan listrik seperti pada penggunaan lampu elektrikal dan pendingin ruangan. Dalam ilmu arsitektur dikenal paling sedikit 4 macam kenyamanan: kenyamanan ruang, penglihatan, pendengaran dan kenyamanan termal. Dalam kenyamanan termal, manusia merasakan sensasi panas atau dingin sebagai wujud respon dari sensor perasa pada kulit terhadap stimuli suhu di sekitarnya. Sensor perasa berperan menyampaikan rangsangan rasa kepada otak, dimana otak akan memberikan perintah kepada bagianbagian tubuh tertentu agar melakukan antisipasi guna mempertahankan suhu tubuh agar tetap berada pada sekitar $37^{\circ} \mathrm{C}$. Hal ini diperlukan organ tubuh agar dapat menjalankan fungsinya secara baik (Karyono, 2001).

Adapun faktor-faktor yang mempengaruhi kenyamanan termal yaitu faktor lingkungan dan faktor personal. Faktor lingkungan meliputi radiasi (radiation), temperatur udara (air temperature), kelembaban udara (humidity), dan pergerakan udara (air movement), sedangkan faktor personal yaitu meliputi pakaian yang dipakai (clo), dan metabolisme tubuh (met).

Kualitas pencahayaan alami yang baik tidak terlepas dari distribusi cahaya yang masuk melalui jendela (bukaan) dan orientasi arah bukaan. Semakin luas bukaan maka akan semakin banyak cahaya yang masuk ke dalam ruangan. Kualitas pencahayaan alami yang baik juga pengaruhi oleh letak bukaan terhadap arah datangnya sinar matahari. Menurut SNI (2001: 2), pencahayaan alami siang hari dapat dikatakan baik apabila (a) pada siang hari antara jam 08.00 sampai dengan jam 16.00 waktu setempat terdapat cukup banyak cahaya yang masuk ke dalam ruangan, (b) distribusi cahaya di dalam ruangan cukup merata dan atau tidak menimbulkan kontras yang mengganggu. Pencahayaan dalam sebuah tempat ibadah tidak hanya mempengaruhi keindahan bangunan saja, kesehatan pengunjung tempat ibadah pun sangat dipengaruhi sejauh mana sebuah tempat ibadah memiliki pencahayaan. Karena itulah merencanakan pembangunan bangunan ibadah memang tidak begitu mudah, setiap orang tentu mengharapkan tempat ibadah yang dibangun dapat memenuhi kriteria sebagai tempat yang indah, sehat, dan nyaman. Keindahan memang bersifat relatif, tapi pencahayaan merupakan hal yang tidak bisa disepelekan begitu saja dalam perencanaannya juga konsepnya.

Vidiyanti (2018) mengatakan bahwa peran bukaan cahaya pada sebuah bangunan turut andil dalam menciptakan kualitas pencahayaan alami yang baik. Perlu direncakan bukaan cahaya yang sesuai dengan lokasi bangunan tersebut. Lubang cahaya yang terlalu besar, dapat mengakibatkan cahaya matahari masuk dalam jumlah besar, yang sekaligus membawa radiasi masuk ke dalam bangunan (Narhadi, 2019). Hal ini mengakibatkan adanya dilema bahwa sinar matahari yang masuk kedalam bangunan akan mempengaruhi kondisi termal ruang. Sehingga dibutuhkan adanya kondisi dimana pencahayaan alami dan penghawaan alami pada ruang menjadi seimbang (Hidjaz, 2018).

Syamsiyah (2013) menyatakan dalam artikelnya bahwa kualitas udara dalam ruang masjid harus terjaga bersih. Udara alami dapat dimanfaatkan optimal melalui system ventilasi silang (cross-ventilation) atau gerakan udara ke atas (stack effect). Arifin dan Hidayat (2018) melakukan penelitian penghawaan alami pada Masjid Jendral Sudirman. Hasil penelitian mengatakan bahwa dari hasil perbandingan untuk suhu udara dengan kenyamanan terbaik terletak pada experimen jendela terbuka sebagian untuk lantai 2 dan lantai 3 sedangkan untuk experimen jendela terbuka semua lebih panas karena aliran angin yang masuk bercampur dengan radiasi yang menimbulkan kinerja suhu didalam ruangan menjadi panas.

Penelitian ini berlokasi di Masjid Al Ahdhar Bekasi. Masjid ini memiliki luas tanah sekitar 1.800 meter persegi dengan luas bangunan 700 meter persegi. Adapun kapasitas masjid dua lantai ini dapat memuat 450 jamaah. Pada konsep bentukan massa bangunan merupakan analogi dari posisi sujud dalam sholat, sehingga kemiringan atap serta kolom- kolom tidak simetris antara yang menghadap ke depan dengan yang ke belakang. 


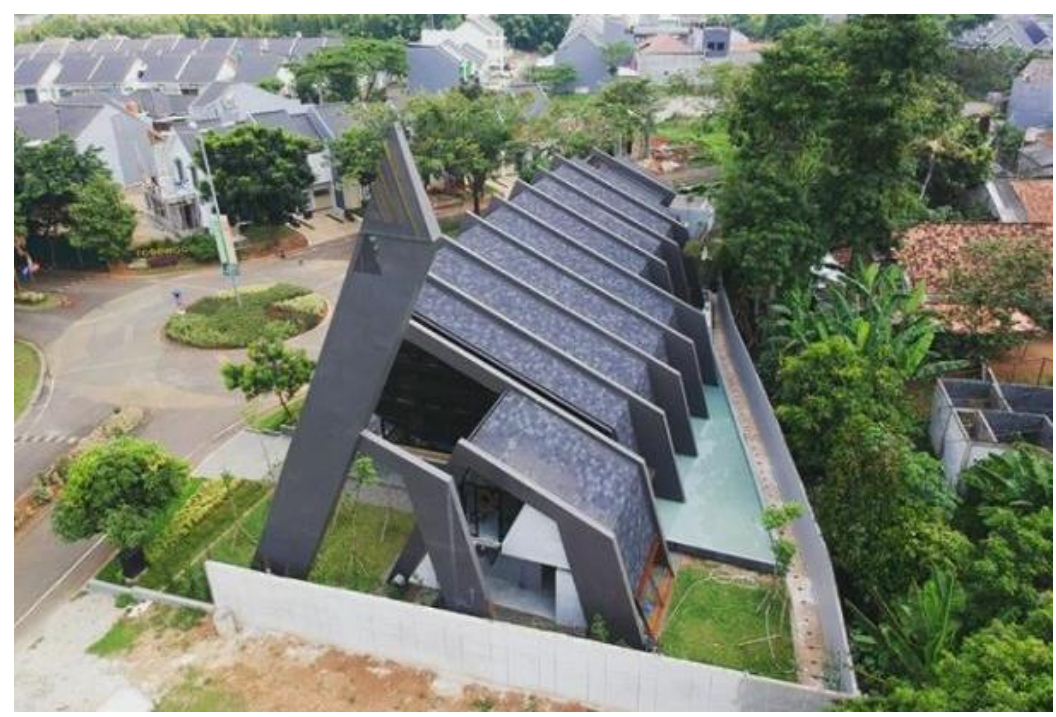

Gambar 1 Bangunan Masjid Al-Ahdhar

Pencahayaan alami dan termal alami merupakan salah satu cara untuk menghemat energi operasional banguann. Desain selubung bangunan atau fasade, orientasi dan luas jendela dapat mempengaruhi besar cahaya yang masuk dan panas matahari yang masuk. Panas yang masuk dalam bangunan berasal dari sumber beban internal dan sumber beban eksternal (dinding atau jendela).

Penelitian ini akan menjawab beberapa rumusan masalah, yaitu (1) mengetahui keadaan pencahayaan alami dan keadaan termal pada masjid Al-Ahdhar; (2) mengetahui pengaruh bukaan bangunan terhadap pencahayaan alami dan kondisi termal masjid Al-Ahdhar; (3) mengetahui hubungan antara pencahayaan alami dan penghawaan alami yang dihasilkan; dan (4) mengetahui kenyamanan termal yang dirasakan oleh responden pada masjid Al-Ahdhar.

\section{Metode Penelitian}

Penelitian ini akan menguji kinerja termal dan pencahayaan alami pada ruang sholat masjid Al-Ahdhar Bekasi. Penelitian ini dilakukan dengan pendekatan kuantitatif. Data analisis yang digunakan adalah hasil dari pengukuran lapangan.

Variabel yang akan diteliti terdiri dari 2 yaitu variabel bebas dan variabel terikat. Variabel bebas yang diteliti adalah fasad bangunan (persentase bukaan bangunan) dan variabel terikat yang diteliti adalah (1) kondisi pencahayaan alami (intensitas cahaya, keseragaman cahaya, kontras pencahayaan); (2) kondisi termal (penghawaan alami) berupa suhu udara, kelembaban udara, kecepatan angin, dan suhu radiasi, dan (3) kenyamanan termal.

Penelitian ini dilakukan di masjid AL-Ahdhar yang Terletak di Perumahan Green Park Jalan Boulevard Raya RT006/RW015 Jati Melati, Pondok Melati Bekasi - Jawa Barat 17446. Pembangunan masjid ini memamng ditujukan untuk bisa menyatu dan beradaptasi dengan lingkungan hijaunya. Masjid ini pun dipilih dengan nama Al-Ahdhar yang artinya Hijau. Masjid ini juga mengadaptasi bangunan masjid pada saat awal perkembangan islam indonesia, yakni berbentuk langgar atau pendopo tanpa dinding, bangunan masjid yang tidak asismetris bangunan masjid merupakan analogi dari posisi sujud dalam shalat. Dengan kondisi lahan yang tidak beraturan pembangunan masjid dibangun mewakili simbol Hablumminallah dan Hablumminannas. Masjid 2 lantai yang bisa memuat sekitar 450 jamaah itu juga mempunyaibangunan kolam pantul serta taman vertikal. Sehingga pandangan jamaah di dalam masjid akan tertuju kembali ke alam yang mengingatkan kembali ke sang khaliq.

Masjid AL-Ahdhar dipilih sebagai lokasi penelitian karena bangunan ini memiliki bentuk yang unik dan konsep hijau yang memiliki bukaan ventilasi yang cukup banyak dan luas tanpa dinding masif, bangunan ini menjadi lebih menarik lagi untuk diteliti karena terdapat AC (Pendingin buatan) ditengah-tengah ruang sholat yang menjadi pertanyaan karena konsep bangunan dan bukaan pada masjid memiliki bukaan yang luas pada setiap sisi apakah belum dapat memberikan kenyamanan termal bagi penggunanya. Oleh karena itu dibutuhkan penelitian kenyamanan termal terhadap penghawaan alami tanpa menggunakan penghawaan buatan. Alat-alat pengukuran untuk mengukur kondisi termal bangunan yang digunakan dalam penelitian ini adalah 
thermometer inframerah, Anemometer, Dry Wet Hygrometer, Thermo Hygrometer. Sedangkan alat pengukuran yang digunakan untuk pengukuran intensitas cahaya matahari adalah Lux Meter.

\section{Hasil dan Pembahasan}

\subsection{Data Observasi Bukaan pada Objek Studi}

Bukaan suatu bangunan dapat mempengaruhi pencahayaan alami dan kondisi termal ruang dalam bangunan. Hal ini dikarenakan bukaan yang terlalu kecil menghasilkan pencahayaan alami yang minim sehingga memungkinkan pencahayaan alami yang dihasilkan di bawah standar yang ditentukan. Bukaan yang terlalu kecil ini pula menghasilkan pergerakan udara yang sedikit. Namun bukaan yang terlalu besar dapat menghasilkan pencahayaan alami yang berlebih. Pencahayaan alami yang berlebih ini tidak baik karena dapat menghasilkan silau yang menyebabkan ketidaknyamanan visual yang dirasakan oleh pengguna. Bukaan yang besar ini pula dapat menyebabkan pergerakan udara di dalam ruang menjadi tinggi yang menyebabkan suhu udara di dalam ruang menjadi rendah. Suhu udara yang terlalu rendah dirasa tidak baik karena pengguna dapat merasa sensasi dingin. Sehingga diperlukan suatu kondisi yang optimal, yaitu kondisi dimana keadaan pencahayaan alami dan penghawaan alami yang memenuhi standar namun juga masih dalam batas kenyamanan pengguna.

Tabel 1 Kondisi bukaan pada sisi Barat
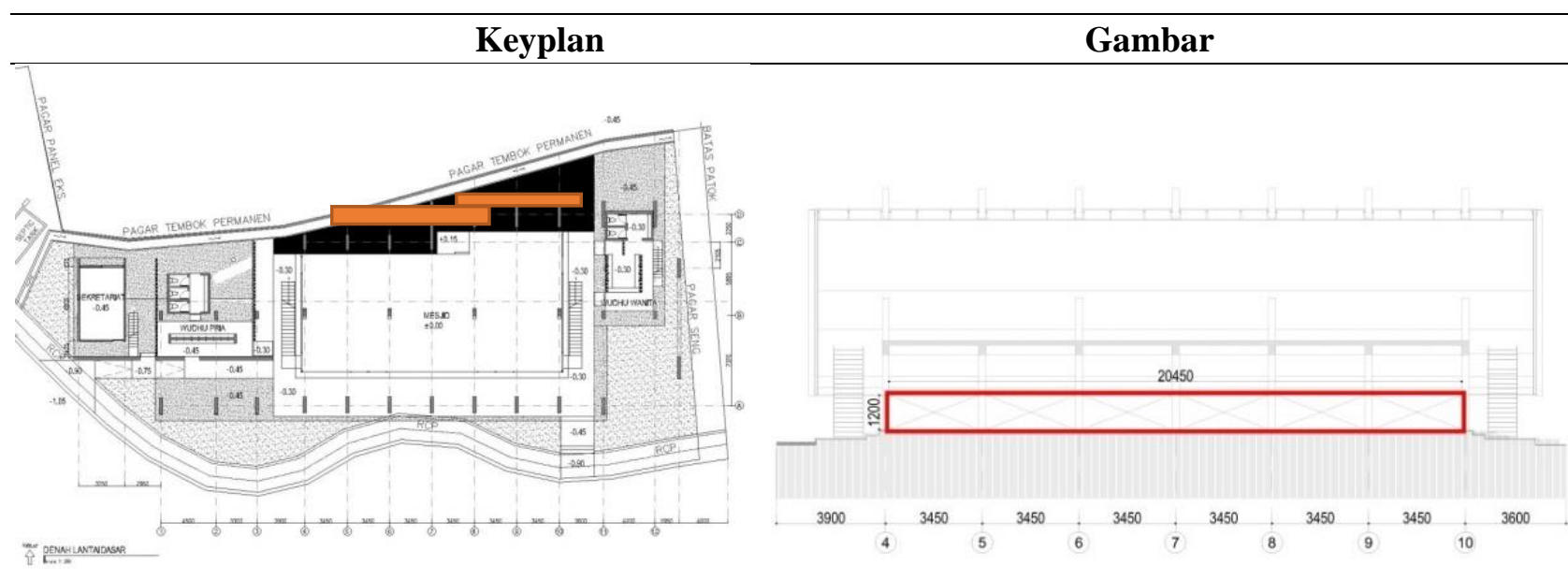

\section{Foto}
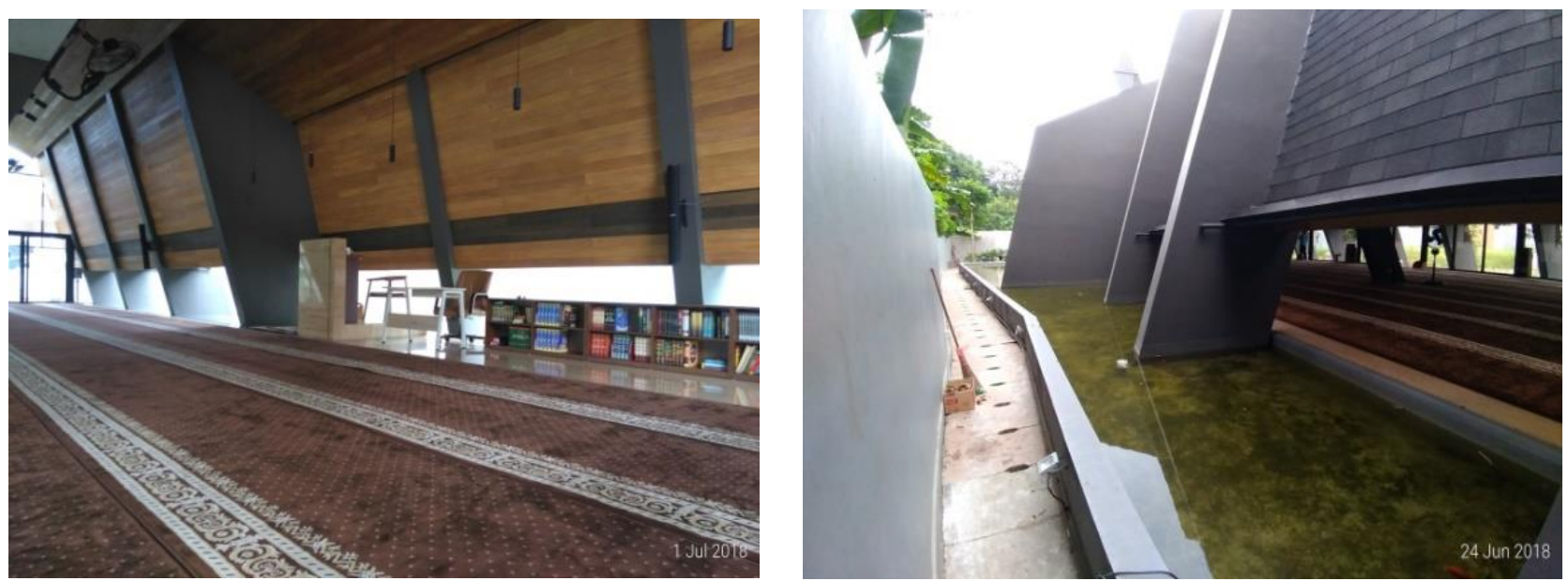

\section{Deskripsi}

Pada sisi depan Ukuran Bukaan full memanjang tanpa sekat, dan terdapat kolam pantul diarea depan, yang membuat area berasa lebih lembab dan sejuk. 


\section{Persentase Bukaan}

Standar SNI 40-80\%

\section{Luas dinding $47 \mathrm{~m} 2$}

Luas bukaan $24 \mathrm{~m} 2$

Luas permukaan fasad $71 \mathrm{~m} 2$

Persentase bukaan $34 \%$

Tabel 2 Kondisi bukaan pada sisi Utara

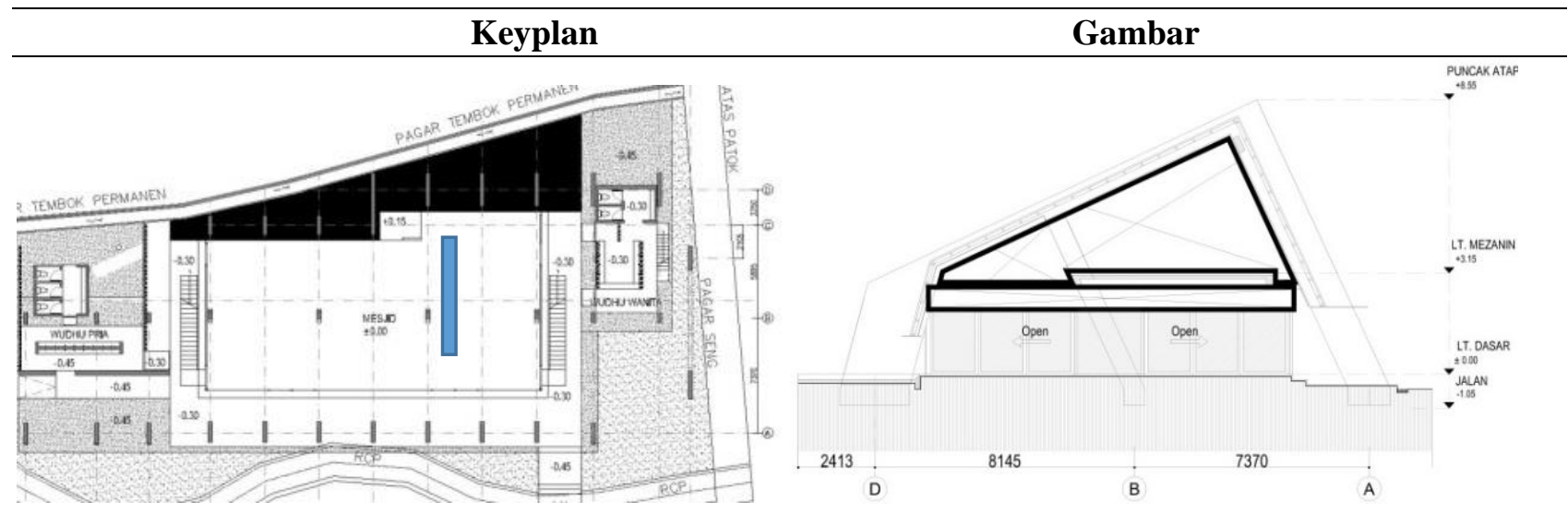

\section{Foto}
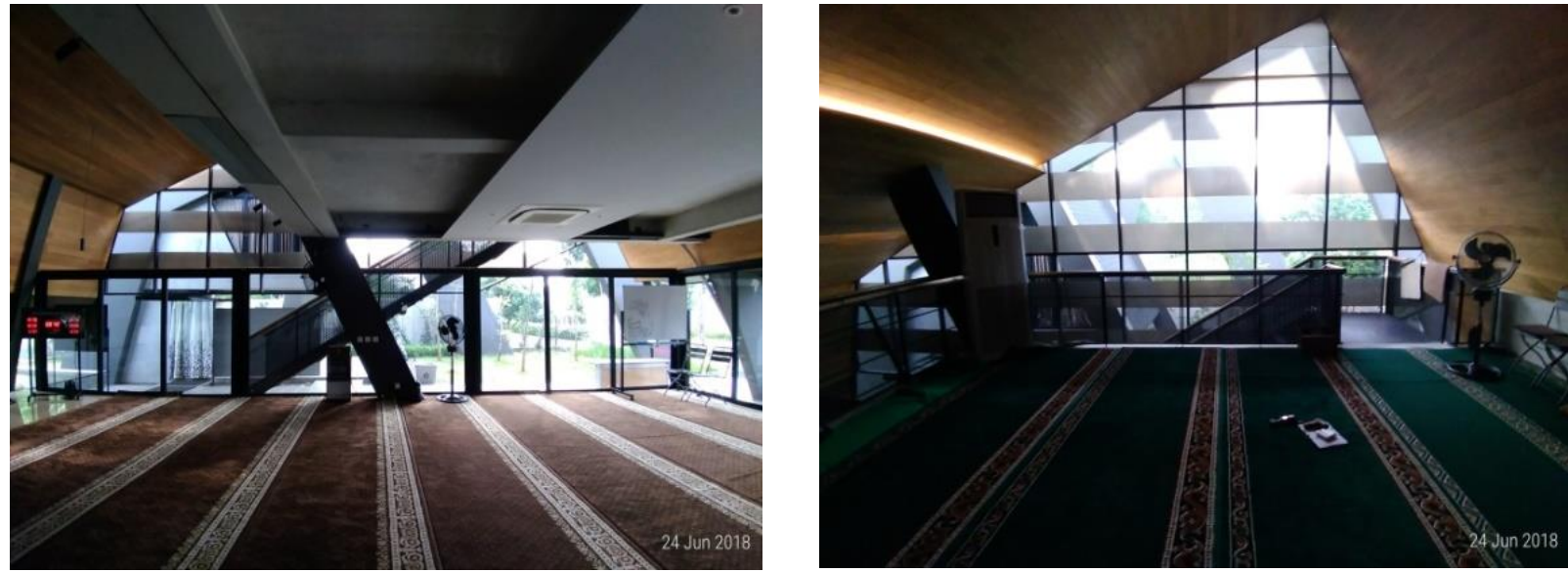

\section{Deskripsi}

Pada sisi samping kanan bangunan berupa dinding kaca dan pintu kaca setinggi 2 meter, pintu kaca bisa digeser full pada setiap sisi untuk memaksimalkan bukaan disaat ruang sholat penuh. Bukaan full dari atas pintu hingga lantai 2 untuk memaksimalkan udara masuk.

\section{Persentase Bukaan}

Standar SNI 40-80\%

Luas dinding $10 \mathrm{~m} 2$

Luas bukaan $39 \mathrm{~m} 2$

Luas permukaan fasad $49 \mathrm{~m} 2$

Persentase bukaan $80 \%$ 


\section{Tabel 3 Kondisi bukaan pada sisi Timur}
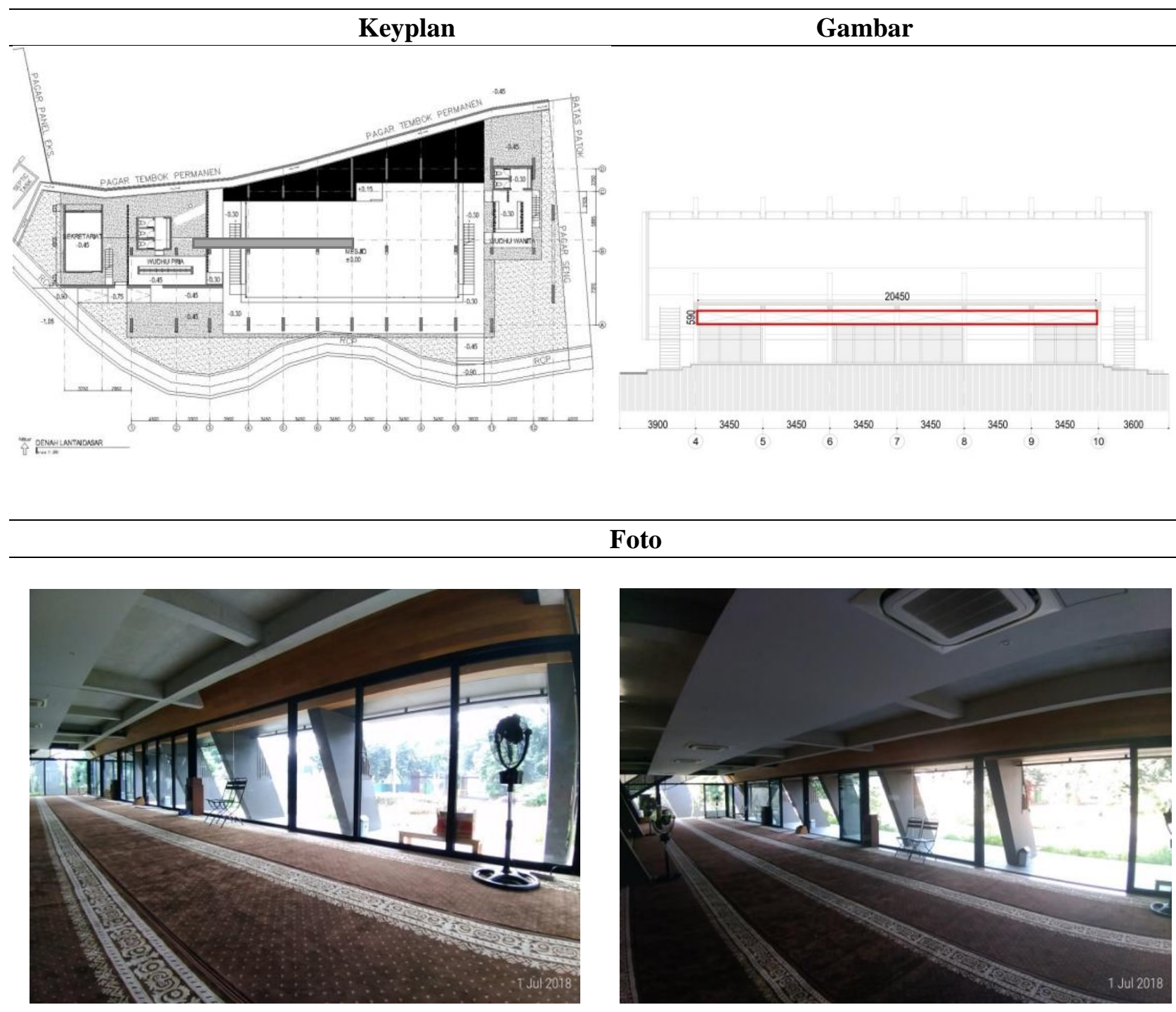

\section{Foto}

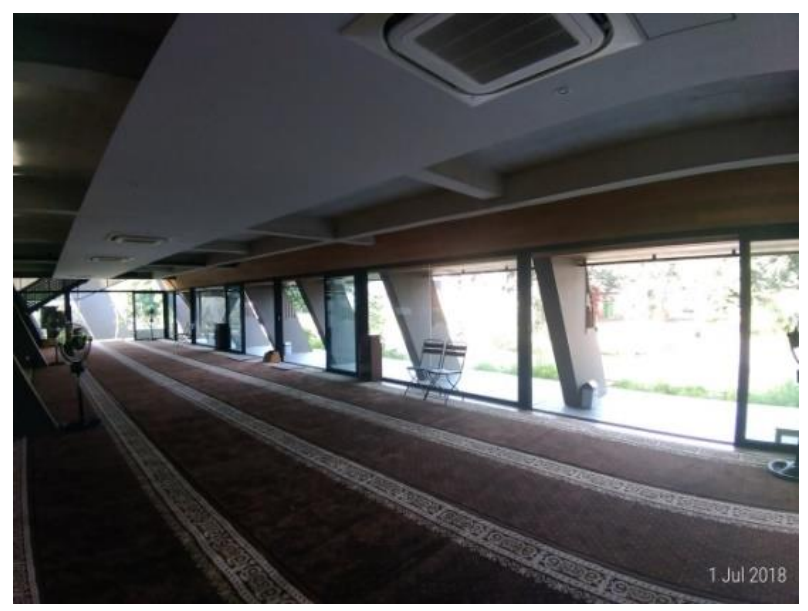

\section{Deskripsi}

Pada sisi depan bangunan berupa dinging kaca dan pintu kaca setinggi 2 meter, pintu kaca bisa digeser full pada setiap sisi untuk memaksimalkan bukaan disaat ruang sholat penuh. Dengan ukuran Bukaan diatas pintu 59x2045 cm.

\section{Persentase Bukaan}

Standar SNI 40-80\%

Luas dinding $22 \mathrm{~m} 2$

Luas bukaan $28 \mathrm{~m} 2$

Luas permukaan fasad $50 \mathrm{~m} 2$

Persentase bukaan $56 \%$ 


\section{Tabel 4 Kondisi bukaan pada sisi Selatan}

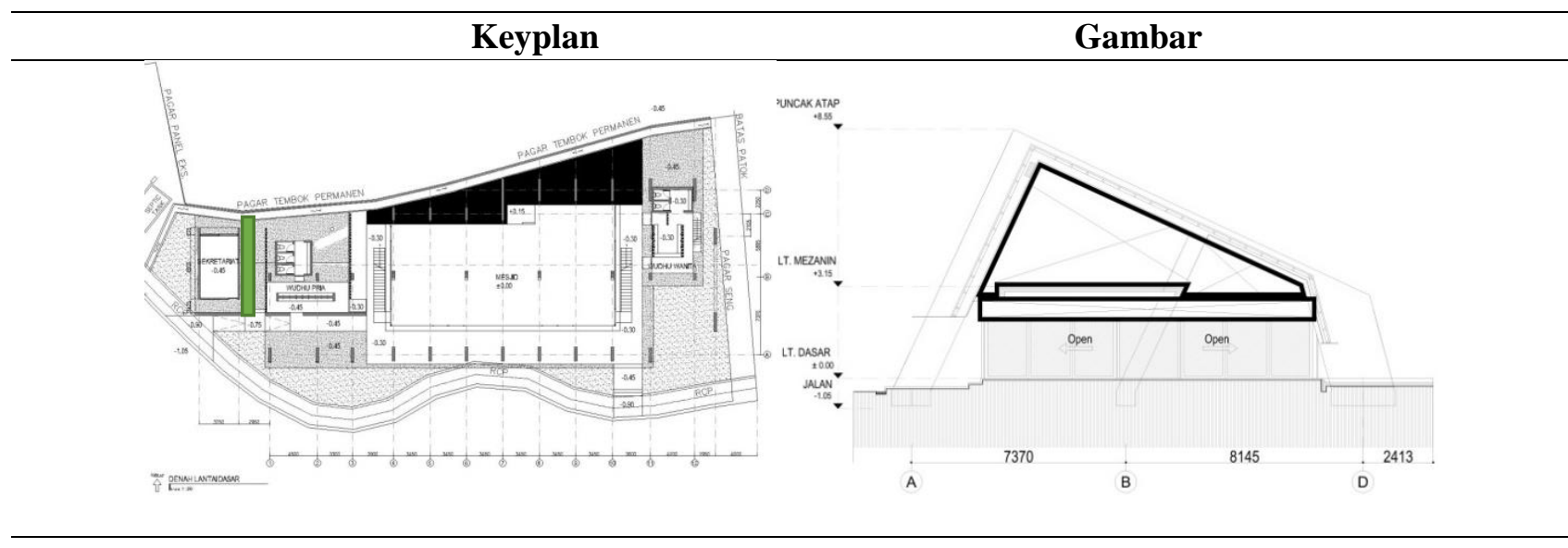

\section{Foto}
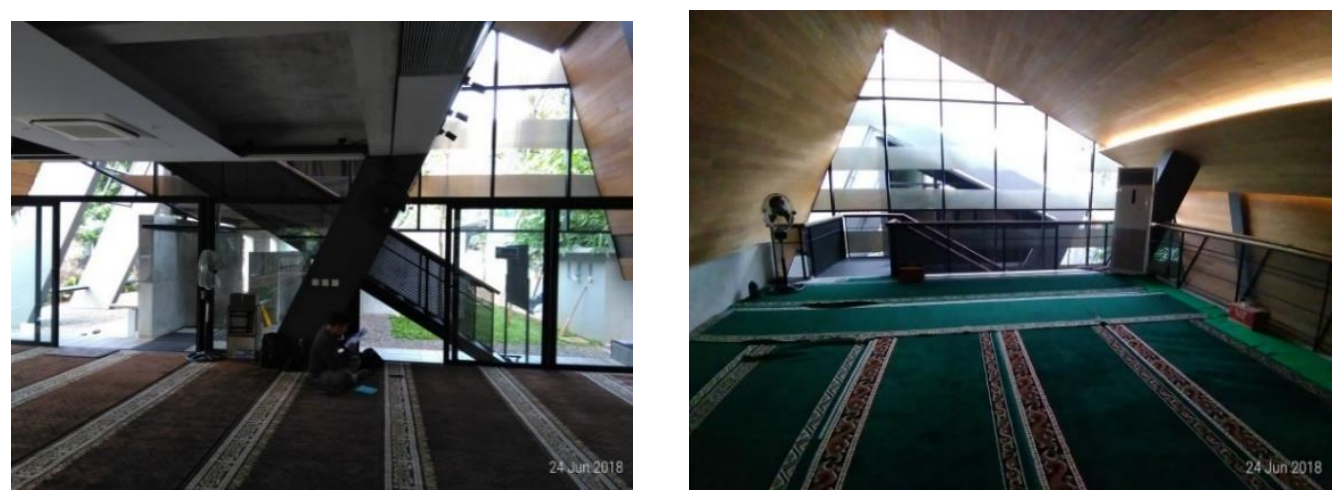

\section{Deskripsi}

Pada sisi samping kanan bangunan berupa dinging kaca dan pintu kaca setinggi 2 meter, pintu kaca bisa digeser full pada setiap sisi untuk memaksimalkan bukaan disaat ruang sholat penuh. Bukaan full dari atas pintu hingga lantai 2 untuk memaksimalkan udara masuk.

\section{Persentase Bukaan}

Standar SNI 40-80\%

Luas dinding $10 \mathrm{~m} 2$

Luas bukaan $39 \mathrm{~m} 2$

Luas permukaan fasad $49 \mathrm{~m} 2$

Persentase $80 \%$

SNI telah menetapkan standar bukaan yang baik pada bangunan adalah sekitar $40-80 \%$. Persentase bukaan tersebut merupakan persentase yang dianggap paling optimal dalam menghasilkan pencahayaan alami dan penghawaan alami yang baik.

Tabel 5 Rangkuman kondisi bukaan masjid Al Ahdhar
\begin{tabular}{ll}
\hline Letak Bukaan & Kesesuaian Bukaan \\
\hline Barat & Tidak sesuai Standar SNI \\
\hline Utara & Sesuai Standar SNI \\
\hline Timur & Sesuai Standar SNI \\
\hline Selatan & Sesuai Standar SNI \\
\hline
\end{tabular}

Dari hasil kesesuaian bukaan terhadap standar SNI, didapatkan terdapat 1 bukaan yang belum memenuhi standar SNI. Bukaan pada sisi Barat hanya 34\%, sedangkan yang direkomendasikan SNI adalah minimal 40\%. Sedangkan bukaan lainnya masih sesuai dengan yang direkomendasikan. 


\subsection{Kondisi Pencahayaan Alami Masjid Al-Ahdhar}

Ruang yang dijadikan sampel penelitian adalah ruang shalat pada masjid Al-Ahdhar. Ruang sholat merupakan ruang inti pada bangunan masjid. Pengukuran dilakukan sebanyak tiga hari dan dilakukan pada tiga interval waktu, yaitu pada pagi hari pukul $08.00 \mathrm{WIB}$, siang hari pukul $12.00 \mathrm{WIB}$, dan sore hari pukul $16.00 \mathrm{WIB}$.

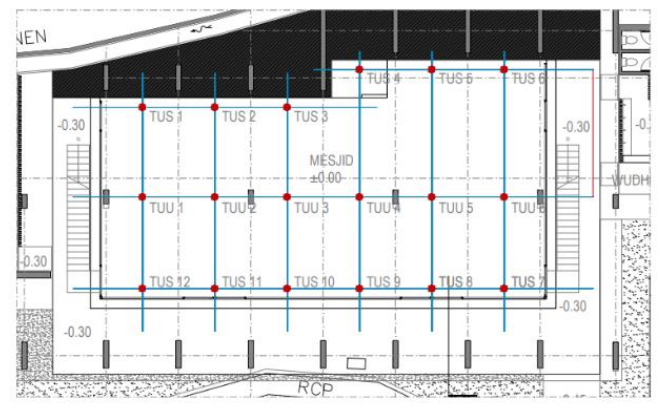

(Lantai 1)

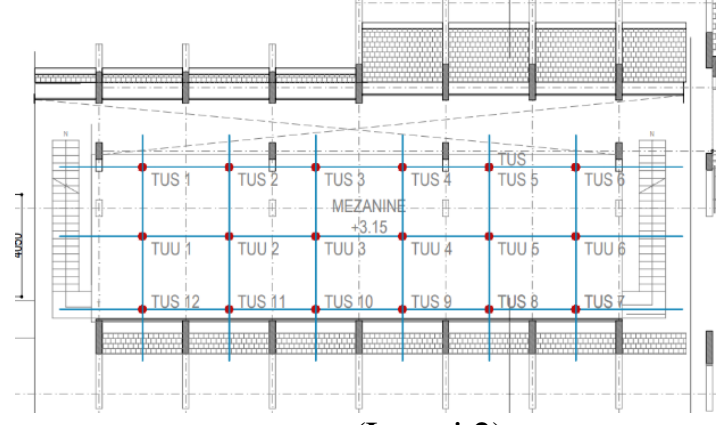

(Lantai 2)

Gambar 2 Denah titik pengukuran cahaya matahari

Dari hasil pengukuran selama tiga hari maka didapat besaran lux rata-rata pada setiap hari, dari hasil rata-rata tersebut akan disimpulkan hasil pencahayaan rata-rata yang ada pada ruang Masjid Al-Ahdhar tersebut. Berikut dibawah ini adalah tabel dan grafik rata-rata pengukuran selama tiga hari dan analisa dari hasil yang didapat.

Tabel 6 Rata-rata tingkat pencahayaan alami pada lantai 1

\begin{tabular}{ccccc}
\hline \multirow{2}{*}{ Hari ke-- } & \multicolumn{2}{c}{ Rata- Rata Hasil Pengukuran (Lux) } & \multirow{2}{*}{ Rata-rata } \\
\cline { 2 - 4 } & Pagi 08.00 & Siang 12.00 & Sore 16.00 & \\
\hline 1 & 306 & 128 & 73 & 169 \\
\hline 2 & 232 & 126 & 35 & 131 \\
\hline 3 & 209 & 137 & 58 & 134 \\
\hline Rata-Rata & 249 & 130 & 55 & 145 \\
\hline
\end{tabular}

Sumber: Survei 2018

Tabel 7 Rata-rata tingkat pencahayaan alami pada lantai 2

\begin{tabular}{ccccc}
\hline \multirow{2}{*}{ Hari ke- } & \multicolumn{2}{c}{ Rata- Rata Hasil Pengukuran (Lux) } & \multirow{2}{*}{ Rata-rata } \\
\cline { 2 - 4 } & Pagi 08.00 & Siang 12.00 & Sore 16.00 & \\
\hline 1 & 257 & 133 & 44 & 145 \\
\hline 2 & 209 & 137 & 58 & 134 \\
\hline 3 & 204 & 119 & 42 & 122 \\
\hline Rata-Rata & $\mathbf{2 2 3}$ & $\mathbf{1 2 9}$ & $\mathbf{4 8}$ & 134 \\
\hline
\end{tabular}

Sumber: Survei 2018

Tabel 8 Rata-rata nilai terang langit selama pengukuran

\begin{tabular}{ccccc}
\hline \multirow{2}{*}{ Hari ke- } & \multicolumn{3}{c}{ Rata- Rata Nilai Terang Langit (Lux) } & \multirow{2}{*}{ Rata-rata } \\
\cline { 2 - 4 } & Pagi 08.00 & Siang 12.00 & Sore 16.00 & \\
\hline 1 & 8,700 & 15,700 & 11,400 & $\mathbf{1 1 , 9 3 3}$ \\
\hline 2 & 7,200 & 11,300 & 10,200 & $\mathbf{9 , 5 6 7}$ \\
\hline 3 & 8,400 & 14,250 & 11,380 & $\mathbf{1 1 , 3 4 3}$ \\
\hline Rata-Rata & $\mathbf{8 , 1 0 0}$ & $\mathbf{1 3 , 7 5 0}$ & $\mathbf{1 0 , 9 9 3}$ & $\mathbf{1 0 , 9 4 8}$ \\
\hline
\end{tabular}

Sumber: Survei 2018 
Pengukuran dilakukan selama tiga hari pada Bulan Juni dan Juli 2018 dengan keadaan langit cerah berawan dan dari hasil pengukuran di dapatkan hasil yang cukup berbeda antara lantai 1 dan lantai 2. Lantai 1 memiliki tingkat pencahayaan alami rata-rata sebesar 145 lux dengan nilai tingkat pencahayaan alami yang memenuhi standar adalah pada pagi hari yaitu memiliki nilai tingkat pencahayaan alami di atas 200 lux. Sedangkan tingkat intensitas pencahayaan alami pada siang hari dan sore hari di lantai 1 masih kurang dari standar karena hanya menghasilkan tingkat pencahayaan alami sebesar 55 lux. Namun nilai 55 lux ini, mata masih dapat melihat namun tidak nyaman untuk beraktivitas sedang seperti membaca.

Lantai 2 memiliki nilai tingkat pencahayaan alami yang cenderung lebih rendah daripada lantai 1, yaitu dengan nilai rata-rata selama 3 hari yaitu sebesar 134 lux. Sedangkan kondisi yang memenuhi standar pencahayaan minimum 200 lux adalah hanya pada pagi hari. Sedangkan pada siang dan sore hari memiliki nilai tingkat pencahayaan alami yang dibawah standar. Lantai 2 memiliki bukaan yang lebih sedikit daripada lantai 1. Hal inilah yang menyebabkan tingkat pencahayaan alami pada lantai 2 lebih rendah daripada lantai 1.

Tabel 9 Kualitas pencahayaan alami pada lantai 1

\begin{tabular}{|c|r|r|r|}
\hline & \multicolumn{1}{|c|}{ Pagi 08.00 } & \multicolumn{1}{c|}{ Siang 12.00 } & \multicolumn{1}{c|}{ Sore 16.00 } \\
\hline Min & 47 lux & 33 lux & 16 lux \\
\hline Average & 253 lux & 128 lux & 66 lux \\
\hline Max & 893 lux & 257 lux & 167 lux \\
\hline $\begin{array}{c}\text { Keseragaman cahaya } \\
\text { Min/Average }\end{array}$ & 0.18 & 0.26 & 0.25 \\
\hline $\begin{array}{c}\text { Kontras Cahaya } \\
\text { Min : Max }\end{array}$ & $1: 19.14$ & $1: 7.70$ & $1: 10.24$ \\
\hline
\end{tabular}

Sumber: Analisis 2019

Tabel 10 Kualitas pencahayaan alami pada lantai 2

\begin{tabular}{|c|r|r|r|}
\hline & \multicolumn{1}{|c|}{ Pagi 08.00 } & Siang 12.00 & Sore 16.00 \\
\hline Min & 43 lux & 27 lux & 9 lux \\
\hline Average & 231 lux & 126 lux & 41 lux \\
\hline Max & 820 lux & 357 lux & 122 lux \\
\hline $\begin{array}{c}\text { Keseragaman cahaya } \\
\text { Min/Average }\end{array}$ & 0.19 & 0.21 & 0.23 \\
\hline $\begin{array}{c}\text { Kontras Cahaya } \\
\text { Min : Max }\end{array}$ & $1: 19.06$ & $1: 13.23$ & $1: 13.04$ \\
\hline
\end{tabular}

Sumber: Analisis 2019

Keseragaman pencahayaan alami yang baik harus berada pada nilai 0.3 sampai dengan 1 (Building Research Establishment, 2016). Namun pada Masjid Al-Ahdhar baik lantai 1 maupun lantai 2 belum ada yang memenuhi nilai keseragaman cahaya yang direkomendasikan. Hal ini berarti masih terdapat perbedaan yang cukup signifikan untuk area yang gelap dengan pencahayaan rata-rata pada ruang.

Sedangkan untuk kontras pencahayaan baik lantai 1 maupun lantai 2 sudah memenuhi rekomendasi kontras pencahayaan menurut SNI yaitu tidak melebihi 1:40. Sehingga pencahayaan alami pada masjid AlAhdhar ini tidak berpotensi menyebabkan silau.

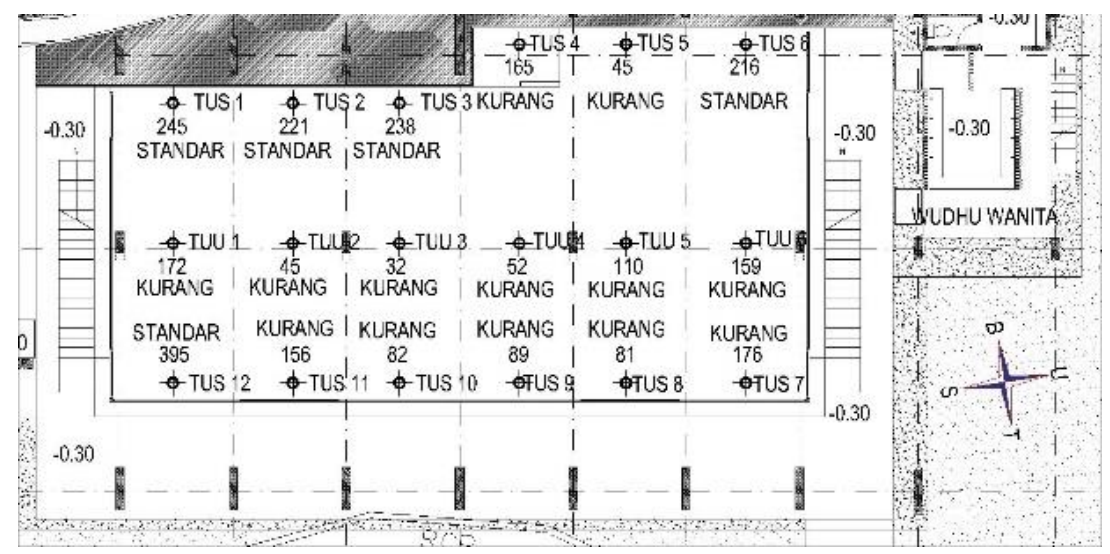

Gambar 3 Kondisi pencahayaan alami pada lantai 1 (Sumber: analisis, 2019) 


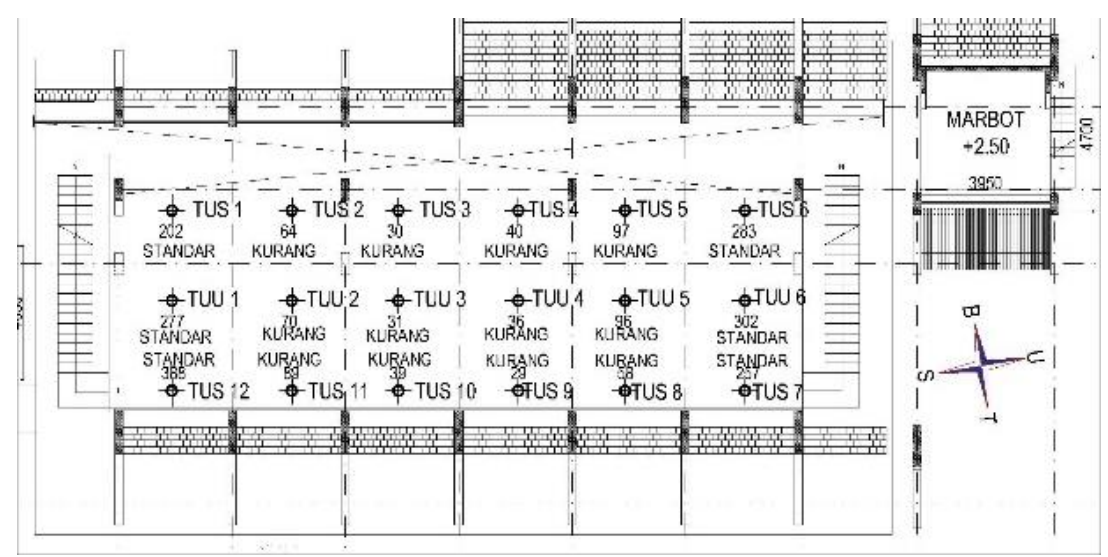

Gambar 4 Kondisi pencahayaan alami pada lantai 2 (Sumber: analisis, 2019)

Tabel 11 Rangkuman persentase bukaan masjid Al Ahdhar

\begin{tabular}{cc}
\hline Letak Bukaan & Persentase Bukaan \\
\hline Barat & $34 \%$ \\
\hline Utara & $80 \%$ \\
\hline Timur & $56 \%$ \\
\hline Selatan & $80 \%$ \\
\hline
\end{tabular}

Kondisi pencahayaan alami pada sisi Barat di lantai 1 cenderung memiliki nilai tingkat pencahayaan alami yang sudah memenuhi standar. Bukaan pada bagian Barat adalah bukaan dengan persentase terkecil yaitu sebesar 34\%. Meskipun memiliki bukaan yang sedikit, namun bagian Barat merupakan jalur perlintasan matahari sehingga sinar matahari yang masuk ke dalam ruang adalah sinar matahari langsung Namun berbeda dengan bagian Barat pada lantai 2 yang mayoritas nilai tingkat pencahayaan alaminya masih di bawah standar. Sisi Barat lantai 2 terhalang oleh fasad masif yang sekaligus menjadi atap pada bangunan ini. Sisi bangunan pada bagian Utara terhalang oleh tangga dan bangunan wudhu yang menyebabkan pencahayaan alami pada lantai 1 menjadi terhalang. Namun, pada lantai 2, keseluruhan sisi Utara dan Selatan memiliki nilai tingkat pencahayaan alami yang memenuhi standar. Sisi Timur memiliki bukaan yang sudah memenuhi standar SNI. Namun begitu ternyata pada sisi Timur, nilai pencahayaan alaminya belum sesuai dengan standar. Pada sisi Timur terdapat kanopi yang cukup panjang sehingga menghalangi sinar matahari yang masuk ke dalam ruang. Bagian tengah ruang baik di lantai 1 maupun di lantai 2 cenderung memiliki pencahayaan alami yang kurang dari standar.

\subsection{Kondisi Penghawaan Alami Masjid Al-Ahdhar}

Kondisi penghawaan alami yang akan dibahas dibagi menjadi beberapa sub topik, yaitu suhu udara, kelembaban relatif, suhu permukaan, dan kecepatan udara. Pengukuran dilakukan selama 3 hari dengan total pengukuran yaitu selama 5 waktu dengan interval setiap 2 jam sekali, yaitu pukul 08.00-10.00, pukul 10.0012.00, pukul 12.00-14.00, pukul 14.00-16.00, dan pukul 16.00-18.00.

Hasil rata-rata suhu udara dalam pengukuran selama 3 hari yaitu pada bukaan bagian Barat dengan luas bukaan sebesar 34\% pada titik 1,6,7,12,13 dan 18 menghasilkan rata-rata suhu sebesar $29.4{ }^{\circ} \mathrm{C}$ (PANAS), bukaan posisi Utara dengan luas bukaan sebesar $80 \%$ pada titik 16,17 dan 18 menghasilkan rata-rata suhu sebesar $29.6{ }^{\circ} \mathrm{C}$ (PANAS), bukaan posisi Timur dengan luas bukaan sebesar 56\% pada titik 3,4,9,10,15 dan 16 menghasilkan rata-rata suhu sebesar $29.4^{\circ} \mathrm{C}$ (PANAS), dan bukaan posisi Selatan dengan luas bukaan sebesar $80 \%$ pada titik $1,2,3$ menghasilkan rata-rata suhu sebesar $29.2^{\circ} \mathrm{C}$ (PANAS), pada posisi tengah area crossing ventilasi di titik $5,8,11,14$ suhu rata-rata sebesar $29.5^{\circ} \mathrm{C}$ (PANAS). Sedangkan pada lantai 2 crossing ventilasi di titik 19,20,21,22,23 dan 24 suhu rata-rata sebesar $30.0{ }^{\circ} \mathrm{C}$ (PANAS), Pada area koridor pada titik 25,26,27 dan 28 suhu rata-rata sebesar $29.7^{\circ} \mathrm{C}$ (PANAS). 


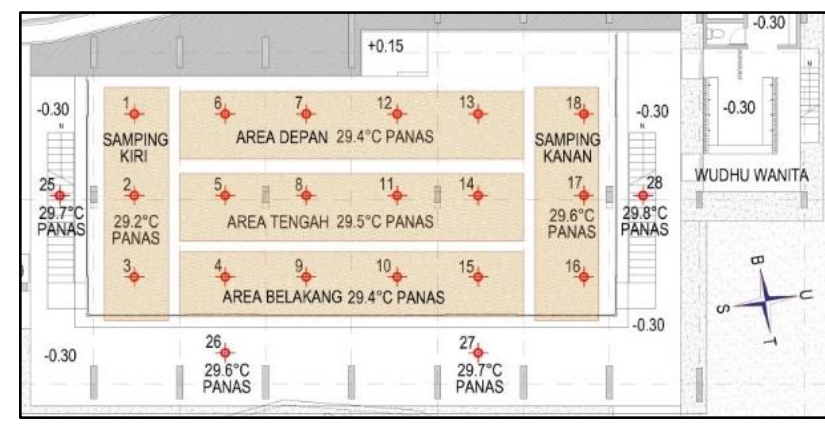

(Lantai 1)

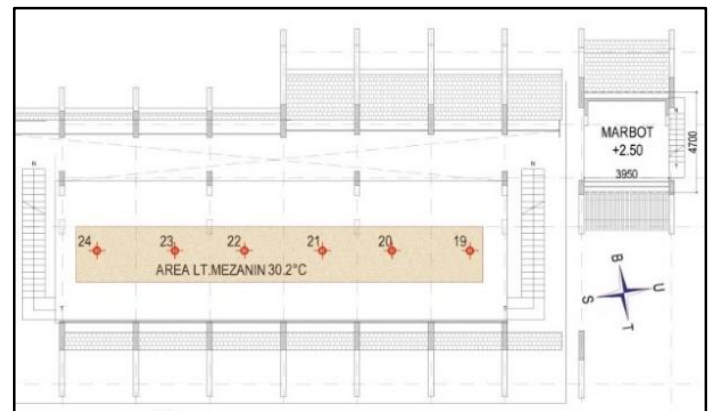

(Lantai 2)

Gambar 5 Zonasi suhu udara (Sumber: analisis, 2019)

Hasil rata-rata kelembaban relatif dalam pengukuran selama 3 hari yaitu, pada bukaan bagian Barat pada titik $1,6,7,12,13, \& 18$ menghasilkan rata-rata suhu sebesar $72 \%$, bukaan posisi Utara pada titik $16,17,18$ menghasilkan rata-rata kelembaban relatif sebesar $72 \%$, bukaan posisi Timur pada titik 3,4,9,10,15,16 menghasilkan rata-rata kelembaban relatif sebesar $72 \%$, bukaan posisi Selatan pada titik 1,2,3 menghasilkan rata-rata kelembaban relatif sebesar $72 \%$, pada posisi tengah area crosing ventilasi di titik 5,8,11,14 kelembaban relatif rata-rata sebesar 72\%, Pada lantai 2 crosing ventilasi di titik 19,20,21,22,23,24 kelembaban relatif rata-rata sebesar 70\%, Pada area koridor pada titik 25,26,27,28 kelembaban relatif rata-rata sebesar $71 \%$.

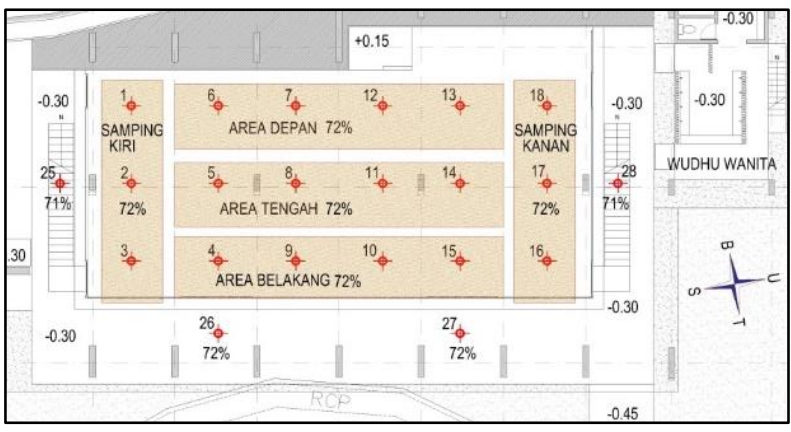

(Lantai 1)

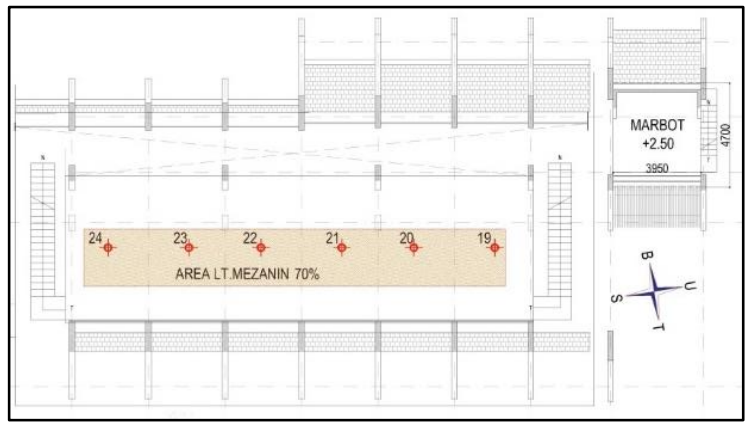

(Lantai 2)

Gambar 6 Zonasi kelembaban relatif (Sumber: analisis, 2019)

Hasil rata-rata suhu permukaan lantai dalam pengukuran selama 3 hari yaitu, pada bukaan Barat titik $1,6,7,12,13,18$ pada suhu $28,9^{\circ} \mathrm{C}$, bukaan Utara titik $16,17,18$ pada suhu $29,1^{\circ} \mathrm{C}$, bukaan Timur pada titik $3,4,9,10,15,16$ pada suhu $28,7^{\circ} \mathrm{C}$, bukaan Selatan pada titik $1,2,3$ pada suhu $29,0^{\circ} \mathrm{C}$, pada crosing ventilasi bagian tengah pada titik $5,8,11,14$ pada suhu $28,6^{\circ} \mathrm{C}$, dilantai 2 pada titik $19,20,21,22,23,24$ pada suhu $30,2^{\circ} \mathrm{C}$.

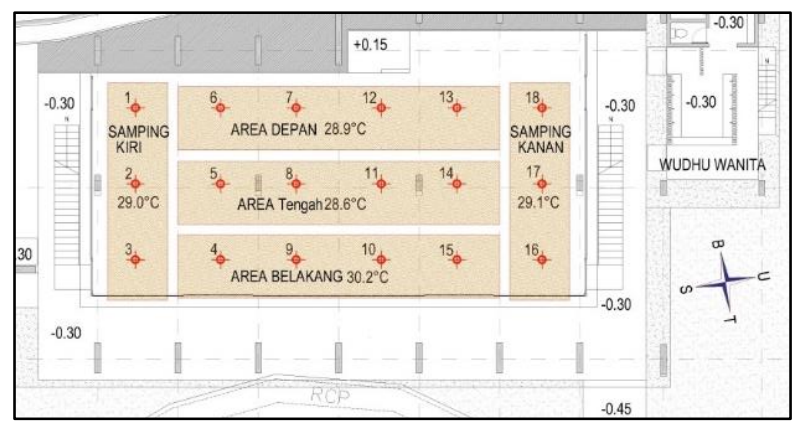

(Lantai 1)

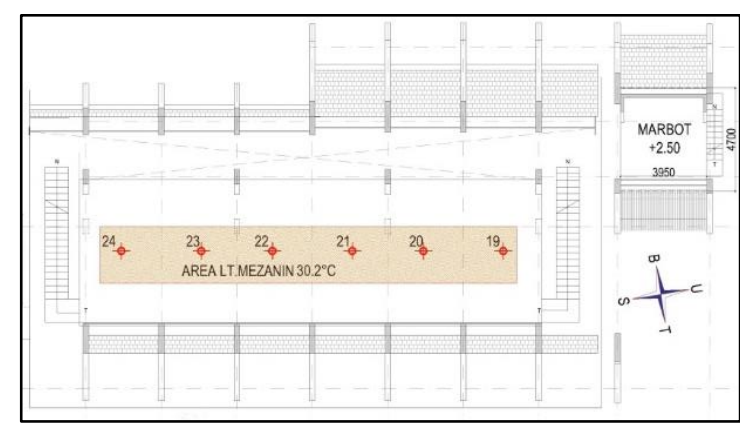

(Lantai 2)

Gambar 7 Zonasi suhu radiasi permukaan lantai (Sumber: analisis, 2019)

Hasil rata-rata suhu permukaan plafon dalam pengukuran selama 3 hari yaitu pada bukaan Barat titik $1,6,7,12,13,18$ pada suhu $30,6^{\circ} \mathrm{C}$, bukaan Utara titik $16,17,18$ pada suhu $29,4^{\circ} \mathrm{C}$, bukaan Timur pada titik $3,4,9,10,15,16$ pada suhu $28,9^{\circ} \mathrm{C}$, bukaan Selatan padda titik $1,2,3$ pada suhu $29,3^{\circ} \mathrm{C}$, pada crosing ventilasi bagian tengah pada titik $5,8,11,14$ pada suhu $28,1^{\circ} \mathrm{C}$, dilantai 2 pada titik $19,20,21,22,23,24$ pada suhu $32,7^{\circ} \mathrm{C}$. 


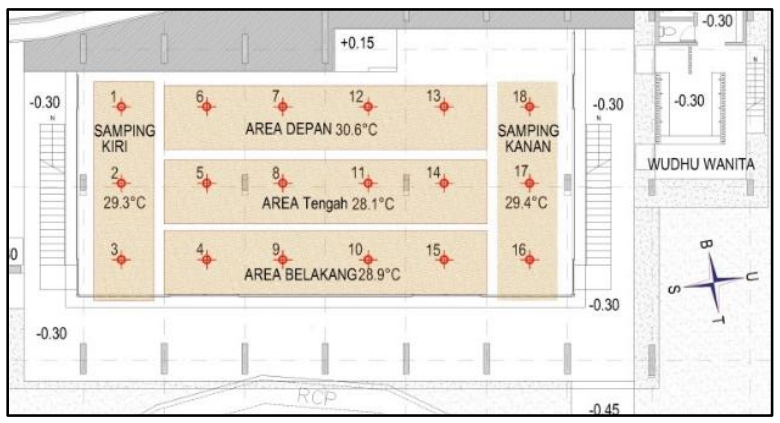

(Lantai 1)

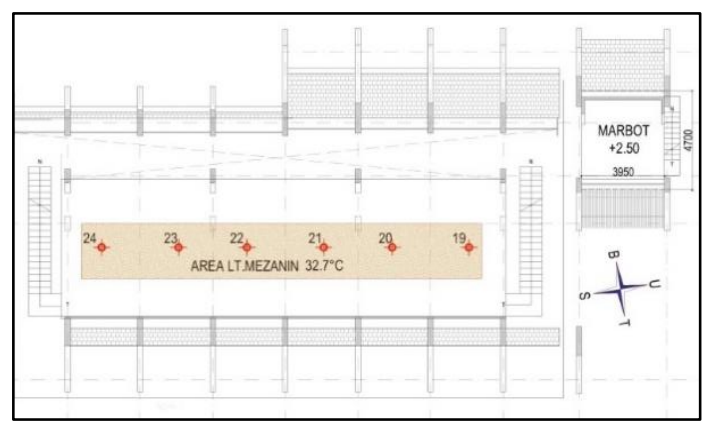

(Lantai 2)

Gambar 8 Zonasi suhu radiasi permukaan langit-langit (Sumber: analisis, 2019)

Hasil Rata-rata suhu permukaan dinding dalam pengukuran selama 3 hari, denga hasil pengukuran suhu dinding dengan rata-rata, pada bukaan Barat titik $1,2,3,4,5,6$ yaitu $29.9^{\circ} \mathrm{C}$, bukaan Utara titik $7,8,9$ yaitu $29.8^{\circ} \mathrm{C}$, bukaan Timur pada titik $10,11,12,13,14,15$ yaitu $29.9^{\circ} \mathrm{C}$, bukaan Selatan pada titik $16,17,18$ yaitu $28.9^{\circ} \mathrm{C}$, dilantai 2 pada titik $19,20,21,22,23,24$ yaitu $30.7^{\circ} \mathrm{C}$.

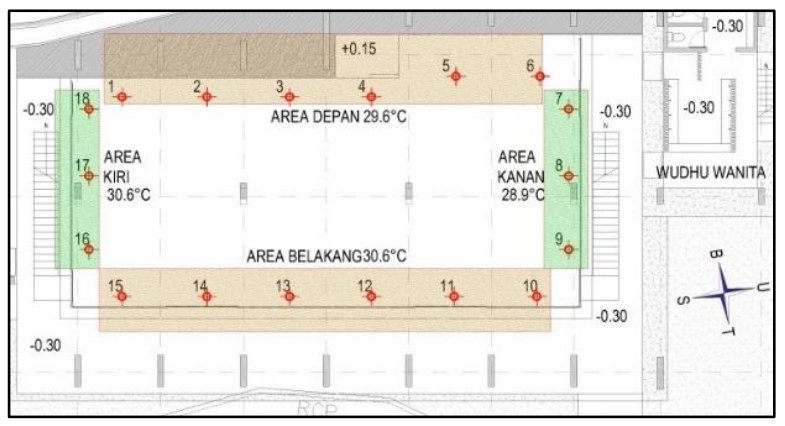

(Lantai 1)

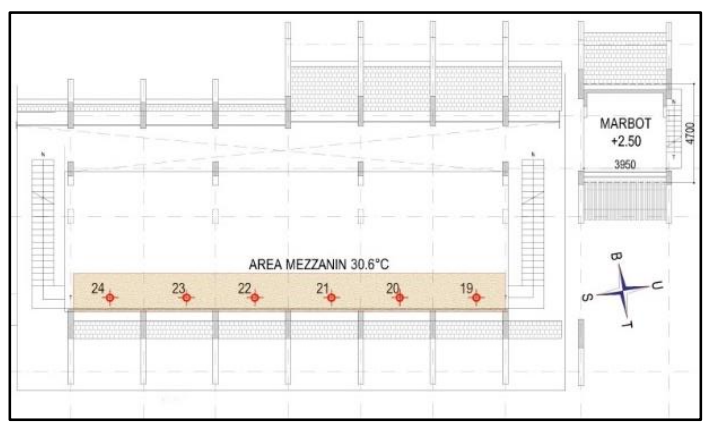

(Lantai 2)

Gambar 9 Zonasi suhu radiasi permukaan dinding (Sumber: analisis, 2019)

Hasil Rata-rata kecepatan angin dalam pengukuran selama 3 hari yaitu, pada bukaan Barat titik $1,2,3,4,5,6$ yaitu $0,71 \mathrm{~m} / \mathrm{s}$, bukaan Utara titik $7,8,9$ yaitu $0,51 \mathrm{~m} / \mathrm{s}$, bukaan Timur pada titik $10,11,12,13,14,15$ yaitu $0,71 \mathrm{~m} / \mathrm{s}$, bukaan Selatan pada titik 16,17,18 yaitu $0,67 \mathrm{~m} / \mathrm{s}$, dilantai 2 pada titik 19,20,21,22,23,24 yaitu $0,72 \mathrm{~m} / \mathrm{s}$, dan pada area koridor pada titik $25,26,27,28$ yaitu $0,64 \mathrm{~m} / \mathrm{s}$.

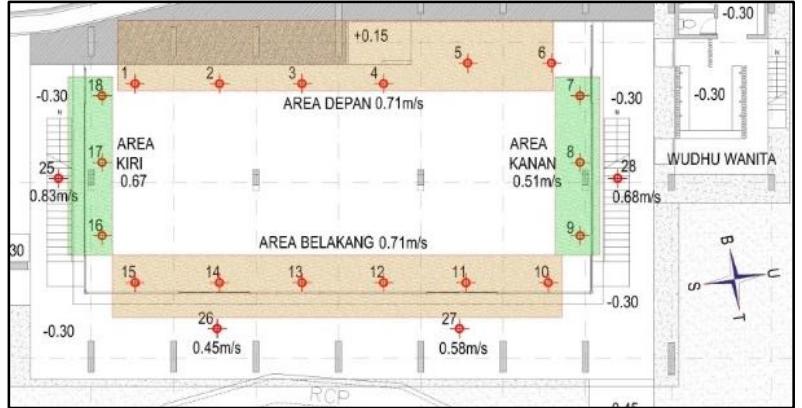

(Lantai 1)

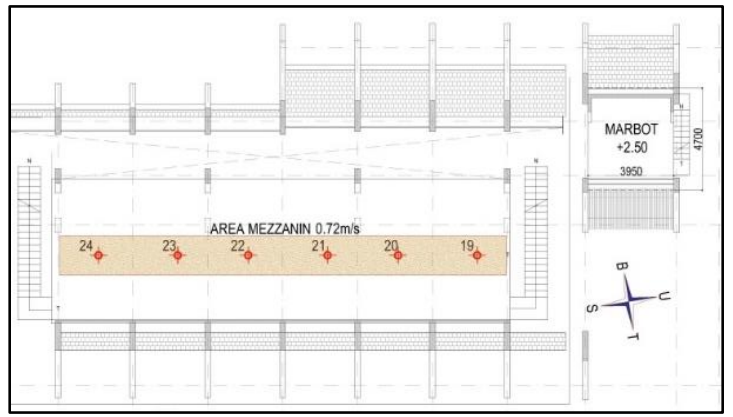

(Lantai 2)

Gambar 10 Zonasi kecepatan udara pada lantai 1(Sumber: analisis, 2019) 


\subsection{Pembahasan}

\section{Pengaruh Bukaan terhadap Kondisi Pencahayaan Alami dan Penghawaan Alami}

Luas bukaan memberikan pengaruh terhadap kondisi pencahayaan alami yang dihasilkan. Dapat dilihat dari hasil pengukuran lapangan, bahwa bukaan yang besar juga akan memasukkan sinar matahari yang tinggi pula. Meskipun begitu ada banyak aspek lainnya yang menentukan pencahayaan alami yang diterima ruang. Orientasi bukaan menjadi hal penting dalam perencanaan pencahayaan alami. Sinar matahari yang masuk pada sisi Timur di pagi hari adalah sinar matahari langsung, sedangkan sisi lainnya menerima sinar matahari difus. Sinar matahari langsung memiliki nilai tingkat pencahayaan yang besar pula. Sinar matahari yang masuk pada sisi Barat di sore hari adalah sinar matahari langsung, sedangkan sisi lainnya menerima matahari difus.

Pada bangunan masjid Al Alhdhar ada banyak sekali penghalang sinar matahari yang masuk, yaitu adanya fasad polikarbonat di depan bukaan pada sisi Utara dan Selatan. Pada sisi Timur terdapat kanopi yang cukup besar sehingga juga menjadi pembayang sinar matahari. Sedangkan sisi Barat terhalang oleh dekatnya jarak bukaan dengan dinding batas tapak. Pada sisi Utara lantai 1 sinar matahari terhalang oleh bangunan wudhu dan pada sisi Selatan lantai 1 sinar matahari terhalang oleh tangga. Titik pengukuran yang memiliki tingkat pencahayaan tertinggi yaitu pada area yang memiliki bukaan yang besar dan tidak terhalang oleh pembayang matahari.

Luas bukaan kurang memberikan pengaruh terhadap kondisi penghawaan alami yang dihasilkan. Hal ini dapat dilihat zonasi suhu udara rata-rata pada ruang memiliki selisih yang tidak signifikan. Suhu udara dipengaruhi oleh kecepatan udara karena angin dapat membawa hawa panas ke luar ruang. Kecepatan udara berpengaruh bukan hanya dengan luas bukaan namun juga dengan tipe bukaan. Bagian Barat dan Timur memiliki bukaan tipe penuh tanpa ada penutup. Hal inilah yang menyebabkan kecepatan udara pada bagian Barat dan Timur cukup besar. Kecepatan udara terendah adalah pada sisi Utara lantai 1, dikarenakan bukaan terhalang oleh bangunan wudhu di samping bukaan sisi Utara. Sisi Selatan juga memiliki kecepatan udara yang lebih rendah dibanding sisi Barat, dikarenakan pada sisi Utara, angin terhalang oleh Tangga.

\section{Hubungan antara Pencahayaan Alami dan Penghawaan Alami}

Semakin dekat bukaan maka pencahayaan alami akan semakin tinggi sedangkan penghawaan alami akan semakin rendah. Begitu pula sebaliknya semakin jauh bukaan maka pencahayaan alami akan semakin rendah dan penghawaan alami akan semakin tinggi. Sehingga bagian dekat bukaan cenderung mendapatkan kondisi yang lebih baik dibanding dengan area tengah ruang.

Tabel 12 Kondisi Pencahayaan Alami dan Kondisi Termal Bangunan

\begin{tabular}{cccc} 
Sisi Bukaan & \multicolumn{2}{c}{ Pencahayaan Alami } & Penghawaan Alami \\
\hline Barat & 188 & $\operatorname{lux}$ & $29.4^{\circ} \mathrm{C}$ \\
\hline Utara & 184 & $\operatorname{lux}$ & $29.6^{\circ} \mathrm{C}$ \\
\hline Timur & 163 & $\operatorname{lux}$ & $29.4^{\circ} \mathrm{C}$ \\
\hline Selatan & 271 & $\operatorname{lux}$ & $29.2^{\circ} \mathrm{C}$ \\
\hline Tengah & 60 & $\operatorname{lux}$ & $29.5^{\circ} \mathrm{C}$ \\
\hline
\end{tabular}

(Sumber: analisis, 2019)

Bukaan sisi Utara terkecuali dikarenakan sisi Utara terdapat jenis bukaan merupakan fixed window yang berarti bukaan yang menggunakan kaca namun tidak dapat dibuka. Sehingga bukaan pencahayaan dan bukaan penghawaan berbeda persentase.

\section{Kenyamanan Termal Masjid Al Ahdhar}

Suhu udara yang dirasakan responden didalam masjid Al Ahdhar tanpa AC dan kipas angin adalah 70\% menyatakan sejuk sedangkan 30\% lainnya menyatakan kurang sejuk. Sebanyak 41,7\% responden menyatakan merasa kelembaban ruangan di dalam masjid. Sebanyak $81,7 \%$ menyatakan bahwa angin yang masuk ke dalam masjid dirasa cukup kecepatannya. Sebanyak $85,3 \%$ menyatakan bahwa jenis bukaan pada masjid cukup untuk mengalirkan udara yang masuk dan keluar. Sebanyak $81,7 \%$ menyatakan bahwa ukuran bukaan sudah cukup baik untuk memenuhi kebutuhan udara pada masjid. Sebanyak $83,3 \%$ menyatakan bahwa jumlah bukaan cukup memenuhi kebutuhan udara pada masjid. Dan sebanyak 66,7\% menyatakan bahwa sinar matahari yang masuk ke dalam masjid menyebabkan suhu udara meningkat. 
Hal ini menandakan bahwa sebagian besar responden merasa sejuk pada masjid Al Ahdhar meskipun kondisi suhu udara pada masjid Al Ahdhar mencapai $29^{\circ} \mathrm{C}$. Responden masih merasa sejuk dikarenakan masih merasa adanya angin atau aliran udara yang masuk ke dalam ruang, sehingga sesekali responden masih merasakan suhu udara rendah yang dibawa oleh angin tersebut.

\section{Kesimpulan}

\section{Kesimpulan}

Kondisi pencahayaan alami pada masjid Al Ahdhar hanya pada pagi hari yang memenuhi standar SNI. Pada siang hari kondisi pencahayaan alami masih mendekati standar SNI, namun pada sore hari kondisi pencahayaan alami jauh dari standar SNI. Kondisi penghawaan alami pada masjid Al Ahdhar meskipun suhu udara pada masjid cukup tinggi namun kecepatan udara pada masjid ini juga cukup tinggi. Sehingga kondisi penghawaan di masjid Al Ahdhar ini tidak pengap.

Luas bukaan memberikan pengaruh terhadap kondisi pencahayaan alami yang dihasilkan. Bukaan yang besar juga akan memasukkan sinar matahari yang tinggi pula. Meskipun begitu ada banyak aspek lainnya yang menentukan pencahayaan alami yang diterima ruang, seperti orientasi bukaan yang berkaitan dengan jenis matahari yang diterima bangunan (sinar matahari langsung atau sinar matahari difus) dan keberadaan pembayang atau penghalang sinar matahari. Luas bukaan kurang memberikan pengaruh terhadap kondisi penghawaan alami yang dihasilkan. Hal ini dapat dilihat zonasi suhu udara rata-rata pada ruang memiliki selisih yang tidak signifikan. Namun luas bukaan berpengaruh terhadap kecepatan udara.

Bukaan pencahayaan alami berbeda dengan bukaan penghawaan alami. Hal ini dikarenakan terdapat beberapa tipe bukaan jenis fixed window yang hanya merupakan bukaan pencahayaan namun tidak menjadi bukaan penghawaan. Semakin dekat area ruang dengan bukaan maka kondisi pencahayaan alami akan meningkat namun kondisi penghawaan alami akan semakin rendah. Dikarenakan pada sisi dekat bukaan kondisi kecepatan udara masih tinggi.

Sebagian besar responden merasa sejuk pada masjid Al Ahdhar meskipun kondisi suhu udara pada masjid Al Ahdhar mencapai dinilai panas oleh standar. Responden masih merasa sejuk dikarenakan masih merasa adanya aliran udara yang masuk ke dalam ruang.

\section{Rekomendasi}

Hasil penelitian ini terbukti untuk masjid Al Ahdhar namun belum dapat dibuktikan untuk kondisi bangunan lain. Sehingga perlu dilakukan penelitian sejenis pada bangunan yang berbeda. Diperlukan perbaikan pada kondisi pencahayaan alami pada masjid Al Ahdhar bias dilakukan dengan menata kembali lemari sehingga tidak menghalangi cahaya alami yang masuk kedalam ruang. Untuk meningkatkan pencahayaan alami dalam ruang juga dapat menggunakan reflektor cahaya.

\section{Referensi}

Arifin, Ikhwan Nur dan Hidayat, M Syarif. Pengaruh Bukaan Terhadap Kinerja Termal Pada Masjid Jendral Sudirman, Jurnal Vitruvian. Vol.7 No.2 Februari 2018 p.67-76.

Badan Standarisasi Nasional. 2001. SNI 03-6572-2001 Tata Cara Perancangan Sistem Ventilasi Dan Pengkondisian Udara Pada Bangunan Gedung. Jakarta: Badan Standarisasi Nasional.

Badan Standarisasi Nasional (2010). Revisi SNI 03-6197: Konservasi Energi pada Sistem Pencahayaan

Badan Standarisasi Nasional (2001). SNI 03-2396-2001 :Tata Cara Perancangan Pencahayaan Alami Siang Hari untuk Rumah dan Gedung

Building Research Establishment (2016). HEA 01 Visual Comfort.

Hidjaz, T. (2018). Arsitektur Mesjid Sebagai Adaptasi Dan Orientasi Ruang. Jurnal Arsitektur Zonasi, 1(1), $1-15$.

Karyono, T H. 2013, Arsitektur dan Kota Tropis Dunia Ketiga, Raja Grafindo Persada, Jakarta.

Narhadi, J. M. S. (2019). Kajian bentuk, fasad, dan ruang dalam pada masjid cheng ho palembang. 2, 183192.

Syamsiyah, Nur Rahmawati \& Suharyani. (2013). Kenyamanan Ruang Dalam Masjid Dan Pembentukan Generasi Islam, Seminar dan Training Kepemimpinan: Peran Islam dalam Membangun Peradaban Umat: Bidang Politik, Sosial, Ekonomi, Pendidikan \& Teknologi.

Vidiyanti, Christy; dkk. Kualitas Pencahayaan Alami Dan Penghawaan Alami Pada Bangunan Dengan Fasade Roster (Studi Kasus: Ruang Sholat Masjid Bani Umar Bintaro). Jurnal Vitruvian. Vol.7 No.2 Februari 2018 p.99-106. 